Dokuz Eylül Üniversitesi-Mühendislik Fakültesi

Fen ve Mühendislik Dergisi

Cilt 20, Sayı 58, Ocak, 2018
Dokuz Eylul University-Faculty of Engineering Journal of Science and Engineering Volume 20, Issue 58, January, 2018

DOI: $10.21205 /$ deufmd. 2018205821

\title{
Yeşil Bilişim Yaklaşımlarıyla Kullanıcı ve Kurum Odaklı Enerji Yönetim Sistemi
}

\section{Muhammet DAMAR* ${ }^{*}$, Yılmaz GÖKŞEN ${ }^{2}$}

${ }^{1}$ Dokuz Eylül Üniversitesi, Bilgi İşlem Daire Başkanlı̆̆ı, 35210, İzmir (ORCID: 00000002-3985-3073)

2 Dokuz Eylül Üniversitesi, İktisadi ve İdari Bilimler Fakültesi, Yönetim Bilişim

Sistemleri Bölümü, 35160, İzmir (ORCID: 0000-0002-2291-2946)

(Alınış / Received: 27.12.2016, Kabul / Accepted: 15.12.2017

Online Yayınlanma / Published Online: 20.01.2018)

Anahtar Kelimeler Özet: İklim değişikliği çözümü için önemli araçlardan birisi bilgi

Enerji,

Yönetim,

Politika,

Yeşil Bilişim

ve iletişim teknolojileridir ve verimlilik artış potansiyeli ile insanoğlunun doğa üzerindeki yıkım etkisinin azaltılmasına katkı sağlayabilen önemli bir araçtır. Bilişimin çevreyle etkileşimi, olumlu ve olumsuz etkiler içermektedir. Çalıșma kapsamında, enerji ve temel kavramlar, enerji yönetimi, enerji verimliliği ve tasarrufu, enerji ve çevre konuları, iklim değişikliği ve bilgi iletişim teknolojileri ilişkisi ve çevreci çözümleri literatür ışığında ele alınmakta, bir kamu birimini daha yeşil hale getirmek için çözümler ortaya konulmaktadır. Çalışmanın amacı; yeșil bilișim konusunda farkındalığı artırmak, çalışanların yeşil bilișim algısını, kullanıcı alışkanlıklarını, teknoloji araçlarının kullanımını ortaya koyarak, tespit edilen ihtiyaçların giderilmesi adına kurum genelindeki süreçlere entegre bir uygulama gerçekleştirmektir. Uygulama, yapılan ihtiyaç analizleri doğrultusunda, kurum içinde yürütülebilecek bir enerji politikası için bir yönetim sistemi kurgulamaktadır. Çalışma, ele alınan süreçlerin, diğer üniversiteler ve kamu kurumları için ortak olması ve örnek teşkil etmesi adına önem taşımaktadır.

\section{User and Institution Oriented Energy Management System With Green IT Approach}

\section{Keywords}

Energy,

Management,

Policy,

Green IT

\begin{abstract}
One of the most important tools for the solution of climate change is information and communication technologies and it is an important tool to reduce the destruction impact of humanity on the nature, with the potential of its productivity enhancements. The interaction of computing environment with the environment contains both positive and negative effects. In the study, energy and basic concepts, energy management, energy efficiency and economy, energy and environmental issues are taken conceptually, climate change and the relationship with the environment friendly solutions of information and communication technologies are discussed according to the
\end{abstract}


literature, and put forward some solutions to accomplish a more green public unit. The purpose of the study; Increasing the awareness of readers related to the subject about the green IT and developing an application integrated to the processes across the organization, by identifying the green IT perception of the personnel, user habits, the use of technology tools. The application implements a management system to construct an energy policy that can be implemented within the organization, according to the requirement analysis. The study creates a model for the common processes of universities and public institutions, thus it has an importance.

*Sorumlu yazar: muhammet.damar@deu.edu.tr

\section{Giriş}

İklim değişikliği, çağımızın ciddi ve karmaşık bir sorunu olarak ortaya çıkmaktadır. Bu sorunun çözümü için önemli araçlardan birisi Bilgi ve İletişim Teknolojileri (BİT)'dir. BİT, barındırdığı verimlilik artış potansiyeli ile insanlığın doğa üzerindeki yıkıcı etkisini azaltmaya katkı sağlayan önemli bir araçtır. BİT kullanımı tüketilen enerji miktarına bağlı olarak sera gazı salınımına neden olabilmektedir. Bu salınım, hizmet veya ürün üretim süreçlerinde kullanılan malzeme veya teknoloji tercihinden, kullanıcıların tüketim alışkanlıklarına değin birçok noktada yapılacak değișiklikler ile azaltılabilir. Bu anlamda kamu kurumları taşıdığı özellikler açısından önemli verimlilik potansiyeli taşıdığı düşünülebilir. Kurumlar, politikalar ve süreçler inşa edebilir; fakat bunu yaşatacak ve sahiplenecek olan kurumların çalışanlarıdır. Kamu kurumlarında yürütülebilecek çevreci politika ve süreçler ile yeşil bilince sahip personel sayısı artırılabilir ve personel üzerinde duyarlılık oluşturulabilir.

Sırasıyla çalışmada; BíT ve iklim değişikliği ilișkisi, BİT kaynaklı iklim değişiklikleri, BİT'in çevreye etkileri, elektronik atık, BíT'de enerjinin kullanımı, elektro manyetik kirlilik ve kaynakların tüketimi, yeşil bilgi ve iletişim teknolojilerinin çerçevesi, daha yeşil BİT için daha yeşil yaklaşımlar (çevre dostu ürün, BİT'de yeşil enerji kullanımı, veri merkezleri ve yönetimi, sanallaştırma, bulut bilişim, yeşil ofisler ve e-atıkların geri dönüşümü) nelerdir, firmaların daha yeşil teknolojilere yaklaşımları ve çözümleri ele alınmaktadır. Uygulama başlığı altında ise, Dokuz Eylül Üniversitesi Sosyal Bilimler Enstitüsü (DEÜSBE) yeşil BİT konusunda mercek altına alınmaktadır. Üniversite içerisinde bilișim teknolojileri neden yeşil olmalı, enerji tüketim kalemleri, kurumun yeşil bilişim teknolojisi algısı, üniversitenin enerji harcamaları ve elektrik tüketim maliyetleri, enerji yönetimi için çözüm olarak bir enerji yönetim programı, yönetim açısından konunun nasıl ele alınabileceği, literatür çerçevesinde açıklanmaktadır. Belirlenen ihtiyaçlar doğrultusunda "Akıllı Enerji Yönetimi: Enerjim" uygulaması gerçekleştirilmekte ve ihtiyaç analizleri ışığında kurum içinde yürütülebilecek bir enerji politikası için bir yönetim sistemi kurgulanmaktadır. Çalışmanın sonuç bölümünde, saha çalışmasında ve uygulamanın geliştirilmesinde elde edilen deneyim ve tecrübe; konu ile ilgili literatür ve araștırmalar ele alınarak bir değerlendirme gerçekleștirilmektedir.

\section{Enerji ve Yönetimi}

Üretimin ana öğesi ve olmazsa olmazı enerjidir. Dünya'da enerji tüketimi bu şekilde devam ederse 2020 yılında fosil yakıt kaynaklarının yarısının tükeneceği tahmin edilmektedir [12]. Bu durum 
enerji yönetimi ve verimlilik kavramlarını ön plana çıkarmaktadır. Yönetim, bir plan oluşturmak ve amaca ulaşmak için, gerekli olan tüm etkinlikleri içermekte [21] ve planla, uygula, kontrol et ve önlem al-düzelt çevriminin tekrarına dayanan, mantıklı ve etkin, amaca ulașmak için gerekli tüm faaliyetleri içermektedir [27]. Enerji verimliliği ise, yeni teknoloji kullanımı ile, kalite ve performansı düşürmeden, sosyal refahı engellemeden enerji tasarrufu sağlanmasıdır [2]. Enerji verimliliği, çoğunlukla, enerji tasarrufuyla karıştırılmaktadır. Enerji tasarrufu ve enerji verimliliği ayrı, ancak birbiriyle ilgili kavramlardır. Enerji ihtiyacını azaltmak ve karbon emisyonunu düşürmek için etkin yol olarak enerji verimliliği düşünülebilir. Așağıda Şekil 1 üzerinde enerji verimliliği ve kazanç arasındaki senaryo 2010-2030 dönemlerinde elde edilen tasarruf miktarı ve yaşam boyu elde edilebilecek tasarruf miktarları şekil üzerinde ifade edilmektedir.

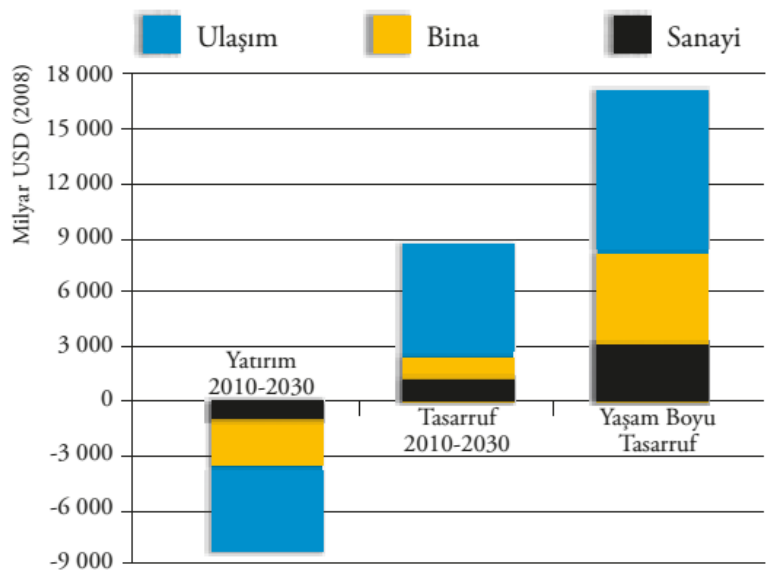

Şekil 1. Enerji verimliliği ve kazanç senaryosu [14]

Enerji üretim alışkanlıklarımızda yapacağımız doğa dostu seçimler ve enerji verimliliğini ön planda tutan yaklaşımlar iklim değişikliğinin engellenmesine katkı sağlamaktadır. Şirketlerin satın alma personellerinden, ailelerin satın aldığı cihazlara ve bu cihazların üretim süreçlerine kadar gelinen noktada kurum ve bireylerin çevreye duyarlı olmaları, enerji tasarrufu sağlamaları önerilebilir.

2011 yll istatistiklerine göre, Türkiye'nin enerji tüketiminin büyük oranla fosil kaynaklarda yoğunlaştığı görülmektedir [24]. Çevre kirliliği ile ilgili problemlerin artmasıyla yenilenebilir enerji kaynaklarının öneminin arttığl düșünülebilir. Bunun yanında, 2025 yılı perspektifinde
Dünya'daki toplam elektrik enerjisi gereksiniminin $\% 10-15^{\prime} l i k$ bölümü yenilenebilir enerji kaynaklarından karşılanacaktır [11].

\section{Bilgi İletişim Teknolojileri (BIT) Ve Yeşil Bilişim}

Yeșil BİT, bilgi ve iletișim teknolojisi ürünlerinde doğaya zararlı malzemelerin kullanımının azaltılması, üretim süreçlerinde geri dönüştürülebilir malzemelere yer verilmesi ve doğaya saygılı davranılmasını, ürünlerin kullanım süreçlerinde verimli kullanımını özetle bir döngü içinde tüm süreçlerin yeşil ve çevreye saygılı hale getirilmesi olarak düşünülebilir. Çevreye saygılı, süreçleri iyileștiren, kaynaklardan tasarruf sağlayan bilgi ve iletişim teknolojileri bu bağlamda "Yeşil 
BİT" kavramını ortaya çıkarmaktadır. Bu yaklaşım için farklı terimler kullanılabilmektedir. Bunlar "Akıllı BíT" veya "Sürdürülebilir BİT" şeklinde ifade edilmektedir [18]. Damar ve diğerleri [9] yeşil bilişimin, bilişim teknolojisi ürünlerinin, üretiminden kullanımına ve yașam ömrünün bitiminden sonra tekrar doğaya zarar vermeden dönüştürülmesine kadar geçen tüm süreçleri kapsadığını belirtmişlerdir.
Türkiye'de bilişim vasıtası ile karbon salınımının azaltılması potansiyeli Şekil 2'de dörtlü bir ölçek ile gösterilmektedir. Çalıșma Türkiye'de ve Dünya'da yenilikçi teknolojilerin farklı sektörlerde kullanım eğilimleri incelenerek oluşturulmuştur. Enerji, üretim, bina ve tarım sektörlerinde değerlendirilebilecek yüksek salınım azaltma potansiyeli bulunmaktadır [32].

\begin{tabular}{l|l|l|l|l|l|l|l}
\hline \multicolumn{2}{l|}{ Yenilikçi Teknolojiler / Sektörler } & Enerji & Ulașım & Üretim & Hizmet & Tarım & Binalar \\
\hline \multirow{2}{*}{ 1. Sayısallaștırma ve Cisimsizleștirme } & Potansiyel & & & & & \\
\hline & Mevcut Durum & & & & & \\
\hline \multirow{2}{*}{ 2. Veri Toplama ve Iletișim } & Potansiyel & & & & & \\
\hline & Mevcut Durum & & & & & \\
\hline \multirow{2}{*}{ 3. Sistem Entegrasyonu } & Potansiyel & & & & & \\
\hline \multirow{2}{*}{ 4. Süreçsel Yönetsel Optimizasyon } & Mevcut Durum & & & & & \\
\hline \multirow{2}{*}{ Yüksek Ortansiyel } & & & & \\
\hline
\end{tabular}

Şekil 2. Türkiye'de bilișim kaynaklı karbon salınım azaltma potansiyeli [32]

BİT sektörü barındırdığı yenilikçi potansiyeli ile küresel ölçekte $\mathrm{CO}_{2}$ salınımında kendi sektörü dışında tüm sektörlerde \%98'e varan $\mathrm{CO}_{2}$ salınımı ve çevreye zararı azaltma, önemli oranda verimlilik artışı sağlama potansiyeline sahiptir. $\mathrm{Bu}$ yenilikçi teknolojilere uzaktan çalışma, telekonferans, akıllı teknolojilere örnek gösterilmektedir [19].

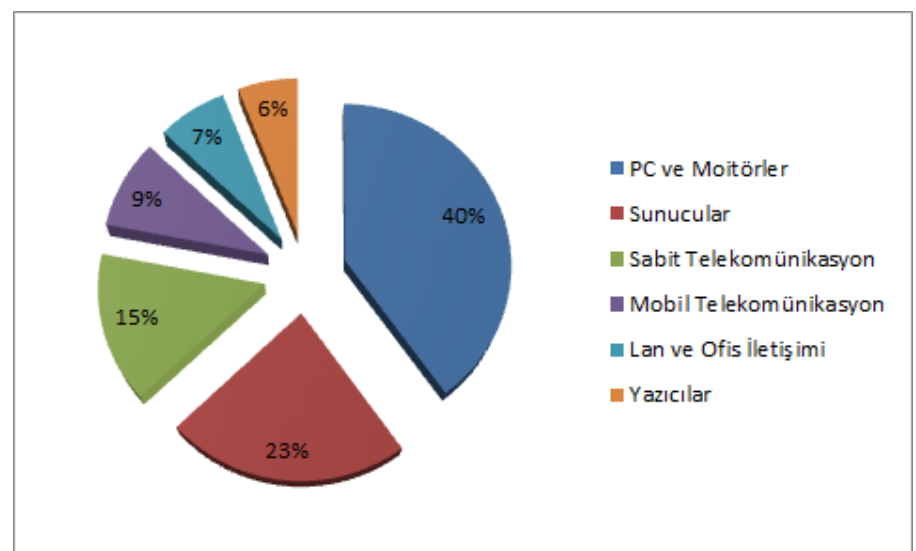

Şekil 3. BİT tarafından yayılan yaklaşık $\mathrm{CO}_{2}$ salınımı [22]

$\mathrm{CO}_{2}$ emisyonunun temel bileșenini, bilgisayar ve monitörler ile veri merkezlerinin enerji tüketimi oluşturmaktadır (Şekil 3). Bu iki grup toplam $\mathrm{CO}_{2}$ salınımının yarısından fazlasını oluşturmaktadır. BİT sektörünün gelişim hızı dikkate 
alındığında oranın giderek artacağı düşünülebilir.

Yeşil bilişim, kavramsal olarak, çevresel etkileri açısından kendinden önceki BİT ürün ve hizmetlerine göre, daha iyi performansa sahip ürün ve hizmetlerin tercih edilmesi, BìT çözümleri ile sürdürülen faaliyetlerde çevreye zararın azaltılması șeklinde ifade edilmektedir [23]. Tablo 1, BİT kullanımına ilişkin özet bir değerlendirme sunmakta, 8 farklı kategoride BİT'in kullanımı ile elde edilen olumlu etki özetlenmektedir.

Tablo 1. BíT kullanımında olumlu etkiler

\begin{tabular}{|l|l|}
\hline Etki Alanı & Etki Durumu \\
\hline $\begin{array}{l}\text { Ürün } \\
\text { tüketimi }\end{array}$ & $\begin{array}{l}\text { Elektronik belge sistemleri sayesinde kağıt tüketiminde önemli oranda tasarruf } \\
\text { sağlanabilir ve çevreye kağıt üretimine bağlı olumsuz etki azaltılabilir. }\end{array}$ \\
\hline $\begin{array}{l}\text { Enerji } \\
\text { tüketimi }\end{array}$ & $\begin{array}{l}\text { BİT aracılığı ile gerçekleştirilebilecek akıllı sulama sistemleri sayesinde su tüketiminde } \\
\text { tasarruflar sağlanabilir ve doğal kaynakların etkin kullanımı sağlanabilir. }\end{array}$ \\
\hline $\begin{array}{l}\text { Kişilerin } \\
\text { taşınması }\end{array}$ & $\begin{array}{l}\text { Kongre, seminer ve benzeri toplantılarda kullanılabilecek video konferans teknolojisi ile, } \\
\text { personel taşınmasına bağlı kaynak tüketiminden ve enerji kayıplarından kaçınılabilir. }\end{array}$ \\
\hline $\begin{array}{l}\text { Ürün taşıma } \\
\text { ve depolama }\end{array}$ & $\begin{array}{l}\text { Lojistik hizmetlerinde BİT uygulamaları ile etkin ürün taşıma sistemleri kurgulanabilir ve } \\
\text { fosil yakıt tüketiminden kaçınılabilir. }\end{array}$ \\
\hline $\begin{array}{l}\text { Ofis içi } \\
\text { verimlik }\end{array}$ & $\begin{array}{l}\text { Akıllı ofis sistemleri ile ofis içi ışıklandırma ve havalandırma gibi sistemler etkinleştirilip } \\
\text { enerji tasarrufu sağlanabilir. }\end{array}$ \\
\hline İş verimliliği & $\begin{array}{l}\text { Geliştirilen uygulamalar ile iş verimliliğinin artması sağlanabilir, kaynak ve enerji } \\
\text { tüketiminde tasarruf sağlanabilir. }\end{array}$ \\
\hline Çöp kutusu & $\begin{array}{l}\text { Cöp miktarı azaltılarak enerjiden tasarrufu sağlanabilir veya çöpler dönüştürülerek etkin } \\
\text { kaynak yönetimi sağlanabilir. }\end{array}$ \\
\hline
\end{tabular}

Not. Güngör ve diğerleri, (2010: 40) çalışmalarından revize edilmiştir [19].

3.1. BíT'in çevre açısından olumsuz Bilgisayar türü cihazların çevreye etkileri

BİT, yaşamımızın her alanına girerken; verdikleri olumsuz etki, yüksek düzeyde eüks túketimleri ve barmdirdiklar sürecinden atıl duruma düșünceye değin, [13]. BİT'in olumsuz etkileri aşağıda çevreye olumlu etkilerinin yanında, Tablo 2 üzerinde 4 kategoride olumsuz etkileri olabilmektedir. açıklanmaktadır.

Tablo 2. BİT'in olumsuz etki sınıflandırması

\begin{tabular}{|c|c|}
\hline Etki & Etkinin Açıklaması \\
\hline $\begin{array}{l}\text { Elektronik } \\
\text { Atık }\end{array}$ & $\begin{array}{l}\text { Herhangi bir faaliyet sonunda çevreye bırakılan her türlü maddeye atık denir [36]. } \\
\text { Ülkemizde, çevre ve insan sağlığını korunması amacıyla, 30.05.2008 tarihli Resmi } \\
\text { Gazete'de; "Elektrikli ve Elektronik Eşyalarda Bazı Zararlı Maddelerin Kullanımının } \\
\text { Sınırlandırılmasına", dair yönetmelik yayımlanmıştır [28]. Elektronik atıklar, Dünya'daki } \\
\text { katı atıkların \%1'ini oluşturmaktadır. Dünya'da her yıl 20-50 milyon ton, Türkiye'de } 300 \\
\text { bin ton elektronik atık çıkmaktadır [17]. }\end{array}$ \\
\hline $\begin{array}{l}\text { Kullanılan } \\
\text { Enerji }\end{array}$ & $\begin{array}{l}\text { Bilişim endüstrisinde en çok } \mathrm{CO}_{2} \text { salınımı kişisel bilgisayarlar ve veri depolarından } \\
\text { yapılmaktadır [22]. Elektronik cihazların artan enerji ihtiyacı, önemli bir sorun haline } \\
\text { gelmektedir ve Avrupa'da yaşayan insanların \%57'si evinde en az bir bilgisayara sahiptir. } \\
2007 \text { yllında konutlardaki bilgisayar ve monitörlerin elektrik kullanımı, toplam evsel } \\
\text { elektrik kullanımının \%2.7'sini oluşturduğu ifade edilmektedir [3]. }\end{array}$ \\
\hline $\begin{array}{l}\text { Elektro } \\
\text { Manyetik } \\
\text { Kirlilik }\end{array}$ & $\begin{array}{l}\text { Yaşadığımız alanlarda bulunan elektrik akımı insan ve diğer canlıların üzerinde olumsuz } \\
\text { etkiler yaratmaktadır [15]. İyonlaştırabilen elektromanyetik ışınımlar, hücrenin genetik } \\
\text { materyali olan DNA'yı parçalayabilecek kadar enerji taşımaktadır. DNA'da çok az bir } \\
\text { zedelenme, kansere yol açabilecek kalıcı değișikliklere sebep olabilmektedir [16]. }\end{array}$ \\
\hline $\begin{array}{l}\text { Doğal } \\
\text { Kaynakların } \\
\text { Tüketilmesi }\end{array}$ & $\begin{array}{l}\text { 2020'li yıllarda kişi başı binlerce bilgisayar ile bilgisayarların altın çağını yaşayacağı } \\
\text { düşünülmektedir [20]. Bu öngörü, elektronik ekipmanlarının üretimi sırasında yoğun ve } \\
\text { doğada nadir bulunan kaynakların kullanımından ötürü düşündürücüdür. Bilgisayar } \\
\text { üretiminde kullanılan kaynak miktarı, diğer ev eşyaları ile kıyaslandığında oldukça } \\
\text { yüksektir. Bilgisayar veya monitör üretiminde minimum } 240 \text { kilogram fosil yakıt, } 22 \\
\text { kilogram kimyasal ve } 1.5 \text { ton su kullanıldığı ifade edilmektedir [1]. }\end{array}$ \\
\hline
\end{tabular}




\section{BİT İçin Yeni Yaklaşımlar}

Günümüzde yeşil ve çevreci yaklaşım hayatımızın birçok alanında karşımıza çlkmaktadır. Artık işletmeler; üretim, tedarik, pazarlama süreçlerinde yeșil kavramını kullanmakta, tüketiciler ürün satın alırken çevreye değer veren işletmelerin ürünlerini almaya dikkat etmektedir. Bilișim sektörü, daha çevreci, daha az enerji harcayan, kurşun ve zararlı maddelerin kullanımının en aza indirildiği ürünleri üretmek için daha çok çalıșmaktadır. Gartner'ın 2008 yılı çevre kirliliğini azaltmaya yönelik raporu [35], BİT yapılanmalarında çevresel faaliyetler için kurumların hareket adımlarını, 10 madde ile özetlemiştir. Bu maddeler aşağıda Şekil 4 üzerinde gösterilmektedir.

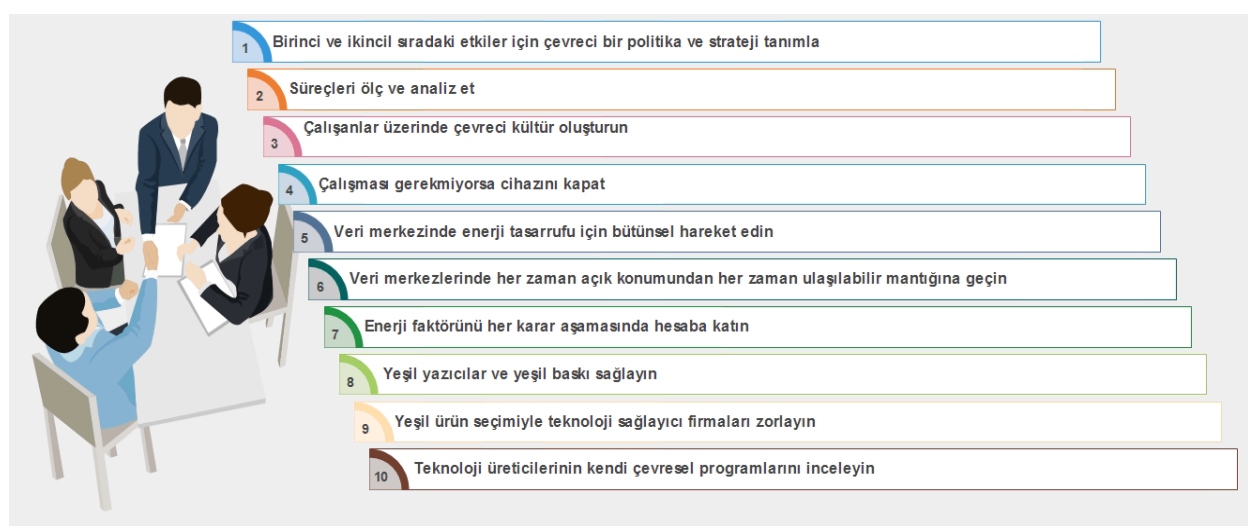

Şekil 4. Yeşil BİT stratejisinin 10 temel hareket noktası [35]

Așağıda BİT sektörü içindeki yeșil ve yenilikçi yaklaşımlar, literatürün kapsamlı bir şekilde incelenmesi ile, 7 başlık altında sınıflandırılmıştır. Bunlar; çevre dostu ürün, BİT’te yeşil enerji kullanımı, veri merkezleri ve yönetimi, sanallaştırma, bulut bilişim, yeşil ofisler, atıkların geri dönüşümü şeklinde sırasıyla açıklanmaktadır (Tablo 3).

Tablo 3. BíT için yeșil yaklașımlar

\begin{tabular}{|c|c|}
\hline $\begin{array}{l}\text { Çevre dostu } \\
\text { ürün }\end{array}$ & $\begin{array}{l}\text { Doğaya zararlı maddenin bulunmadığı, yenilenebilen enerji ve malzeme ile üretilen, } \\
\text { doğaya zararlı ambalajlanmayan, son ürün formunda zararlı kimyasal madde } \\
\text { barındırmayan, kullanım süresi sonrası geri dönüştürülebilen veya yok edilmesi } \\
\text { sürecinde doğaya zarar vermeyen ürün olarak tanımlanmaktadır [7]. Örneğin HP } \\
\text { firması bu noktada "Kolayca Anlaşllır Yeşil BiT" (Green IT for Dummies) adıyla } \\
\text { İngilizce bir doküman oluşturmuştur [29]. Biliş̧im sektöründeki firmanın bu tür bir } \\
\text { doküman hazırlaması firmanın sadece ürünlerin üretim ve satıșı ile ilgilenmediğini; } \\
\text { ürünlerin doğaya saygllı kullanımına da önem verdiğini göstermektedir }\end{array}$ \\
\hline $\begin{array}{l}\text { Bilişimde enerji } \\
\text { kullanımı }\end{array}$ & $\begin{array}{l}\text { BİT araçlarının daha akıllı kullanımıyla enerji kazanımı söz konusudur. Bu durum özel } \\
\text { ve kamu kurumları için bir kurumsal kültür haline getirilmesi gereken davranıșlardır. }\end{array}$ \\
\hline $\begin{array}{l}\text { Veri merkezleri } \\
\text { ve yönetimi }\end{array}$ & $\begin{array}{l}\text { Bilişim sektöründeki enerji harcamalarındaki başrol, sistem odalarındaki enerji } \\
\text { sarfiyatıdır [4]. BİT kaynaklı } \mathrm{CO}_{2} \text { salınımında en büyük pay sistem odaları ve sistem } \\
\text { odalarının sağlıklı bir şekilde faaliyetlerini sürdürmesi için yürütülen faaliyetlerden } \\
\text { kaynaklanmaktadır [22]. Bunun yanında sistem odalarının iklimlendirilmesi için } \\
\text { harcanan enerji, veri merkezlerinde tüketilen enerjinin yaklaşı \% } \% 30 \text { 'una karşlık } \\
\text { gelmektedir [6]. Veri merkezlerinde kullanım önerisi olarak, bulut teknolojisi ve } \\
\text { sanallaștırma daha yeşil teknoloji olarak sunulabilir. }\end{array}$ \\
\hline Sanallaștırma & $\begin{array}{l}\text { Sanallaştırma veri merkezleri için olmazsa olmaz bir teknoloji haline gelmekte, teknik } \\
\text { altyapının yönetimini kolaylaştırmakta, işgücü ve zamandan büyük oranda tasarruf } \\
\text { sağlamaktadır. Sanallaştırma sayesinde veri merkezindeki fiziksel sunucuların sayısı } \\
\text { azaltılabilir, enerji, soğutma gibi işletme giderleri azaltılabilir ve bu şekilde daha yeșil } \\
\text { bir veri merkezleri oluşturulabilir. Merkezi ve etkin yönetim sistemi ile yönetimsel } \\
\text { karmașa minimize edilerek kaynakların daha etkin kullanımı sağlanabilir. }\end{array}$ \\
\hline
\end{tabular}




\begin{tabular}{|c|c|}
\hline Bulut bilişim & $\begin{array}{l}\text { İhtiyaç duyulan veri ve hesaplamaların tüketici bilgisayarı yerine uzaktaki } \\
\text { sunucularda tutulması mantığına dayanmaktadır. Geleneksel iş uygulamalarının } \\
\text { karıșık ve pahalı olması bulut bilgi işlemin gelişiminin önünü açmaktadır [25]. } \\
\text { Christopher Mines'ın "Neden Bulut Yeşil Bir Çözümdür; Bunun İçin } 4 \text { Neden" [26] } \\
\text { yazısında klasik bilgi işlem ve bulut bilgi işlem arasında farklarda, bulut bilgi işlemin } \\
\text { en önemli iki özelliği; kaynak diğeri ise enerji olarak ifade edilmiştir. Kaynak ve enerji } \\
\text { israfı bulut bilgi işlem ile engellenir, kaynak etkinliği sağlanır. }\end{array}$ \\
\hline Yeşil ofisler & $\begin{array}{l}\text { Araştırmaya göre, bir kurumun bilgilerinin } \% 80 \text { - \%95'i kağıt ile elektronik ortamda } \\
\text { saklanabilmektedir [10]. Ofis ortamında, kullanılmayan ofis malzemelerinin } \\
\text { kapatılması, ihtiyaç dışı kullanımının önüne geçilmesi gerektiği düşünülebilir. Bu } \\
\text { durum hem finansal hem de çevresel olarak kurumlara büyük bir mali yük } \\
\text { getirmektedir. Bir ofis çalışanı yılda ortalama } 10.000 \text { yaprak kağıt kullanmakta ve bir } \\
\text { yaprak kağıt üretimi için } 390 \text { gram suya ihtiyaç duyulmaktadır. Yazılım çözümleri } \\
\text { etkin kullanıldığında, enerji, şirket giderleri, kağıt yapımında kullanılan kaynaklar } \\
\text { konusunda verimlilik ve kaynak tasarrufu sağlanmaktadır [7]. }\end{array}$ \\
\hline $\begin{array}{l}\text { Bilişim sektörü } \\
\text { atıklarının geri } \\
\text { dönüşümü }\end{array}$ & $\begin{array}{l}\text { Teknolojinin hızlı ilerlemesi ile, yeni ürün modelleri piyasaya sürülmekte, teknolojisi } \\
\text { geçen cihazlar çalışır halde olsa bile çöp haline gelmektedir. Bugün bu noktada hızla } \\
\text { artan yeni bir atık türü olan elektronik atık ile karşı karşıya bulunmaktayız. Elektronik } \\
\text { atıklar, doğada kapladıkları yer ve içerdikleri zehirli maddelerden ötürü Dünya'da } \\
\text { büyüyen bir sorundur [8]. Günümüzde bazı ülkeler, elektronik atıkları, geri dönüşüm } \\
\text { için toplamakta ve hammadde olarak kullanılabilmektedir. }\end{array}$ \\
\hline
\end{tabular}

\subsection{Kurumların yeşil BíT algısı}

Turkcell, baz istasyonlarındaki enerji ihtiyacı için yenilenebilir enerji kaynaklarını tercih etmektedir. GreenCell projesi adı verilen bir proje ile baz istasyonu elektriğinin temininde rüzgar enerjisinden faydalanmaya bașlamıștır. Bu sayede $738000 \mathrm{kWh}$ enerji tasarrufu sağlamıș ve $\mathrm{CO}_{2}$ emisyonunu 500 ton azaltmıștır. Turkcell aynı zamanda akıllı teknolojiler ile firmalara enerji tasarrufu ve verimlilik sağlayacak çeşitli hizmetlerde bulunmaktadır [30]. Așağıda Tablo 4 üzerinde, kurumların iç süreçlerinde kullanabilecekleri BİT çözümlerinin faydaları gösterilmektedir.

Tablo 4. BİT'in çevreci kullanım örnekleri ve kazanımları [19]

\begin{tabular}{|l|l|}
\hline BİT çözümleri & Faydaları \\
\hline Uzaktan çalışma & $\begin{array}{l}\mathrm{AB}-25 \text { ülkelerinde, çalışanların \% 10'unun işlerini uzaktan yapması yılda } 22 \text { milyon } \\
\text { ton } \mathrm{CO}_{2} \text { tasarrufu sağlayabilir. }\end{array}$ \\
\hline Ses-konferansı & $\begin{array}{l}\mathrm{AB}-25 \text { ülkelerinde, yıllık konferans katılımında fiziksel katılım yerine ses-video } \\
\text { konferansın tercih edilmesi, yılda } 2128 \text { milyon ton } \mathrm{CO}_{2} \text { tasarruf sağlayabilir. }\end{array}$ \\
\hline Video konferans & $\begin{array}{l}\mathrm{AB}-25 \text { ülkelerinde, iş gezilerinin \%20'sinin video konferanslar ile yapılması yılda } \\
\mathrm{CO}_{2} \text { tüketimini } 22.35 \text { milyon ton azaltabilir. }\end{array}$ \\
\hline $\begin{array}{l}\text { Online telefon } \\
\text { faturalandırması }\end{array}$ & $\begin{array}{l}\mathrm{AB}-15 \text { ülkelerinde tüm abonelere online faturalandırma yapılmasıyla yılda } \mathrm{CO}_{2} \\
\text { tüketimi } 1.03 \text { milyon ton azaltılabilmektedir. }\end{array}$ \\
\hline $\begin{array}{l}\text { Web tabanlı } \\
\text { vergi iadesi }\end{array}$ & $\begin{array}{l}\mathrm{AB}-25 \text { ülkelerinde, vergi iadelerinin internet üzerinden gerçekleştirmesi ile yıllık } \\
\mathrm{CO}_{2} \text { tüketimi } 195790 \text { ton azaltmaktadır. }\end{array}$ \\
\hline
\end{tabular}

Bir bașka örnek; 2009 yılında Samsung elektronik firmasıdır. Firma 50 nanometre işlemci teknolojisi ile Dünya'nın ilk 4 gigabytle Ddr3 Dram mod ürününü geliştirmiștir. Bu sayede daha yüksek kapasiteli bellek ihtiyacının giderilmesi için önemli bir gelişme kaydedilmiştir. Düşük enerji tüketimi için özel olarak tasarlanan 4 gigabyte Ddr3 Dram 1.35 voltla çalıșmakta ve 1.5Voltla çalıșan Ddr3'e göre \%20 daha çok iş üretmekte ve $\% 40$ daha az enerji harcamaktadır [7]. Bir başka örnek ise Türk Telekom firmasıdır. Firma çalışanları üzerinde oluşturduğu çevreci kurum kültürüyle enerji tasarrufu ve karbon salınımına dikkat çekmektedir. Firma binalarında kullanılan akıllı sistemler ile elektrik tüketiminde yılda 1.5 milyon kWh, doğalgaz tüketiminde 3.5 Milyon kWh tasarruf sağlamıştır [31]. 


\section{Uygulama}

\subsection{Uygulama alanının yeşil bilişim yaklaşımı ile incelenmesi}

Çalışmada DEÜSBE yeşil bilişim açısından mercek altına alınmakta ve ihtiyaçların doğru belirlenmesi için kurum personeline ve yetkililere çeșitli formlar uygulanmaktadır. Bunlardan ilki, "Yetkili Görüşme Formu" dur. Kurum hakkında genel bilgilerin alındığı, uygulanan ilk formdur. Sorular; BİT kullanımını, laboratuvar sayısını, kurumun kullandığı teknolojileri sorgulamaktadır. Bu sayede, kurum içi durum, BİT envanter sayısı gibi çalışmayı etkileyebilecek veriler sistematik bir șekilde toplanmaktadır. Bir diğer form ise "Kullanıcı Görüșme Formu"' dur. Kullanıcıların BİT kullanım alışkanlıklarını öğrenmeye yönelik bir formdur. Bu form, toplamda 3 boyuttan olușmaktadır. Boyutlar; kullanıcının demografik özellikleri, kullanıcı alışkanlıkları ve yeşil bilișim konusunda değerlendirme șeklindedir. Uygulanan bu formlara ek olarak seçilen bazı BİT cihazlarının enerji tüketimleri elektronik enerji ölçüm cihazı ile hesaplanmaktadır.

Yapılan tüm bu incelemeler sonucunda kurum ihtiyaçlarına dönük, "Akıllı Enerji Yönetimi: Enerjim", programı Dokuz Eylül Üniversitesi Bilgi Sistemine
(DEBİS) entegre bir şekilde inşa edilmektedir. Geliştirilen uygulamanın yazılım yaşam döngüsü içindeki test süreçleri dahil tüm adımları gerçekleştirilmiş, diğer üniversite ve kurumlara örnek olabilecek, gerçek saha verilerine ve ihtiyaçlara göre tasarlanmış, fakat aktif olarak kullanım için idari kararları bekleyen bir uygulamadır.

\subsection{Kurum içi enerji tüketim kalemleri}

Kurum içi enerji tüketim kalemleri belirli gider kalemleri altında sınıflanmaktadır. Örneğin bütçe giderlerinde 03-02-03 enerji alımlarını ifade eder. Giderlerin takibi ve kontrolünün sağlanabilmesi için kayıt altına alınıp izlenebilmesi gerekir. Gerçekleştirilen uygulamada tüketim giderleri Tablo 5 üzerinde ifade edilen gruplara göre yapılmaktadır. Bu sayede kurumun giderlerinin Maliye Bakanlığ Bütçe Sınıflandırılmasına uygun sinıflanması ve kontrolü sağlanabilmektedir. Tablo 5 üzerinde Dokuz Eylül Üniversitesi (DEÜ) üzerinde enerji giderleri ve sinıfi 2011, 2012, 2013, 2014 ve 2015 dönemleri için gösterilmektedir. İlgili tablo ile kurum içi enerji giderlerinin büyüklüğü ve giderlerin genel bütçe içindeki yeri görülebilmektedir.

Tablo 5. DEÜ analitik bütçe sınıflandırması kodlarına göre yıl bazlı enerji giderleri

\begin{tabular}{|c|c|c|c|c|c|c|}
\hline Kodu & Sınıf İsmi & 2011 & 2012 & 2013 & 2014 & 2015 \\
\hline $\begin{array}{l}03 / 2 / \\
3 / 01\end{array}$ & $\begin{array}{l}\text { Yakacak } \\
\text { Alımları }\end{array}$ & 2.523 .090 & 2.036 .681 & 2.467 .693 & 2.000 .479 & 2.587 .750 \\
\hline $\begin{array}{l}03 / 2 / \\
3 / 02\end{array}$ & $\begin{array}{l}\text { Akaryakıt ve } \\
\text { Yağ Alımları }\end{array}$ & 446.113 & 407.485 & 531.279 & 603.130 & 573.499 \\
\hline $\begin{array}{l}03 / 2 / \\
3 / 03\end{array}$ & $\begin{array}{l}\text { Elektrik } \\
\text { Alımları }\end{array}$ & 5.562 .050 & 11.335 .429 & 8.930 .638 & 4.988 .153 & 5.941 .886 \\
\hline $\begin{array}{l}03 / 2 / \\
3 / 90\end{array}$ & $\begin{array}{l}\text { Diğer Enerji } \\
\text { Alımları }\end{array}$ & 1.130 .124 & 1.814 .203 & 858.378 & 1.139 .106 & 1.132 .537 \\
\hline $\begin{array}{l}03 / 2 / \\
3 \\
\end{array}$ & $\begin{array}{l}\text { Enerji Alımları } \\
\text { (Genel Toplam) }\end{array}$ & 9.661 .379 & 15.593 .799 & 12.787 .988 & 8.730 .869 & 10.235 .674 \\
\hline- & Toplam & 353.234 .583 & 379.771 .628 & 392.693 .477 & 461.281 .443 & 502.064 .511 \\
\hline 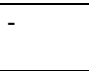 & $\begin{array}{l}\text { Bütçede Enerji } \\
\text { Alımları Oranı }\end{array}$ & $\% 2.73$ & $\% 4.1$ & $\% 3.25$ & \%1.89 & $\% 2.03$ \\
\hline
\end{tabular}

Not. DEÜ, Maliye bakanlığı bütçe giderlerinin ekonomik sınıflandırması 2011-2015 tablolarından revize edilmistir. 


\subsection{Kurum BİT cihaz envanteri} DEÜ 2011-2015 Stratejik Planına [33] ve 2015 Performans Raporuna [34] göre, DEÜ içerisinde fakülte, yüksekokul ve müdürlüklerde, bir bilgi işlem yapılanması olsa da; bilgi ve iletişim teknolojileri faaliyetleri Rektörlük Bilgi İșlem Daire Bașkanlığı tarafından işletilmektedir. 2011-2015 Stratejik planı çerçevesinde; BİT sınıflandırması: Teknolojik kaynaklar, internet ve bilgisayar, DEÜ kütüphane otomasyon sistemi, bilgisayarlar, kütüphane kaynakları ile diğer BİT kaynakları şeklindedir. Tablo 6'da kurum içi aktif kullanımdaki BíT ürünlerinin türleri ve sayıları görülebilmektedir.

Tablo 6. 2015 Performans raporuna göre BiT kaynak grupları ve sayısı [34]

\begin{tabular}{|l|r|}
\hline Bilgi ve İletișim Teknolojileri Kaynak Grupları & Miktar \\
\hline Bilgisayar ve Sunucular & 16.132 \\
\hline Bilgisayar Çevre Birimleri & 4.504 \\
\hline Teksir ve Çoğaltma Makineleri & 248 \\
\hline Haberleșme Cihazları & 5.568 \\
\hline Ses, Görüntü ve Sunum Cihazları & 4.778 \\
\hline Seminer ve Sunum Amaçlı Ürünler & 1.924 \\
\hline Görsel ve İșitsel Kaynaklar & 7 \\
\hline Öğrenmeyi Kolaylaștırıcı Ekipmanlar & 2.072 \\
\hline Kontrol ve Güvenlik Sistemleri & 858 \\
\hline Toplam & 36.091 \\
\hline
\end{tabular}

5.4. Kurum içi enerji yönetim programının yürütülmesi ve enerji politikası

Enerji verimliliği çalıșmalarının odak noktasında enerji yönetimi bulunmaktadır. Tüm yönetim faaliyetleri gibi enerji yönetimi; planlama, koordinasyon ve kontrol gibi süreçlerden meydana gelmektedir. Çalıkoğlu'na [5] göre basit işletme tedbirleriyle enerji verimliliğinde \%10'a varan oranlarda iyileşmeler sağlanabilmektedir. Üniversite içindeki enerji giderleri (Tablo 5), BİT ürünlerinin miktarları (Tablo 6) ve analizlerden elde edilen veriler ıșığında, kurumda bir enerji yönetim çalışması gerçekleştirmenin ve politika oluşturmanın kuruma olumlu bir etki yaratacağı ortaya çıkmaktadır. Kurum içi gerçekleştirilen incelemeler ve görüşmeler sonucunda, kurum içesinde enerji yönetim programına dair herhangi bir uygulama veya faaliyete rastlanmamıştır. Kurum içinde enerji kalemlerinin takibini sağlayan bir birim söz konusudur. Birimin görevleri arasında enerji verimlilik çalışması, tasarruf önlemleri, kurum içi enerji politikası güdülmesi gibi etkinlikler söz konusu değildir. Enerji politikasının yürütülmesi için DEÜ yapısına uygun yapılanma aşağıda gösterilmektedir (Şekil 5 ve Şekil 6).

Kurumda enerji politikasının yürütülebilmesi için politikanın tüm personel tarafından sahiplenmesi gerekmektedir. Personelinin enerjinin verimli kullanımı ve tasarrufu üzerine, sorumluluklarının olduğunun farkında olmaları gerekmektedir. Bu bağlamda, kurum için personel bilinçlendirme çalışması yürütülmelidir ve bu çalışma, eğitim, iletişim, davranış değiştirme ve değerlendirme bölümlerinden oluşmaktadır [5]. Enerji politikasının birim sorumlularınca etkin bir şekilde yürütülebilmesi için DEBİS'e entegre ve tüm kurum kullanıcıların ulaşabileceği bir yapı gereklidir. Özellikle kurum içi eğitim ve bilinçlendirme çalışmaları için iletişim sistemi kritik bir önem taşımaktadır. Tüm bu ihtiyaçlar göz önüne alınarak, enerji yönetim sistemi yazılımı "Akıllı Enerji Yönetimi: Enerjim" programı DEÜ ihtiyaçlarına uygun bir şekilde kurgulanmıştır. 


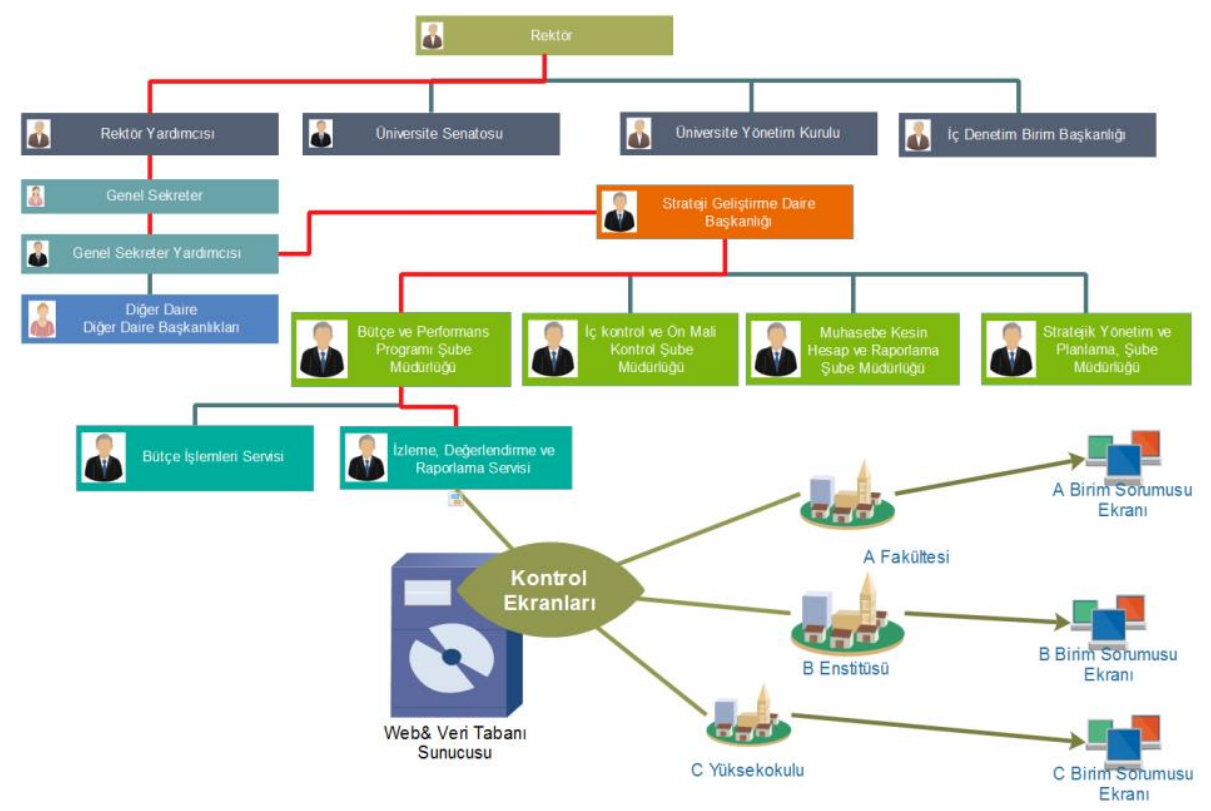

Şekil 5. Kurum idari teşkilat şeması üzerinde enerji yönetim süreci kurgusu

\section{Enerji Yönetim Sistemi Yazılımı}

Aktarılan fizibilite çalışmaları sonrasinda, istemci sunucu mimarisi ile çalışan ve DEBİ'e entegre, tüm kullanıcıların rahatlıkla ulaşabileceği yazılım gereksinimi ortaya çıkmıştır. Geliştirilen program, kurum içinde yürütülebilecek bir enerji politikası için yönetim sistemi kurgulamayı amaçlamaktadır.

\subsection{Yazılım teknolojileri}

Geliştirilen bu yazılım, enerji yönetimi sağlayabilmesi, enerji giderlerinin kayıt altına alınıp izlenmesini sağlaması, üst yönetime ve birimlere iyileştirmelerin raporlanmasına imkan sağlaması adına önemlidir. Tabi bunun yanında, birim içi haber paylaşımı, birim içi mesajlaşma, eposta atabilme, faydalı dokümanları kullanıcılar ile paylaşabilme ve kullanıcı işlemleri gibi çeşitli fonksiyonlara sahiptir. $\mathrm{Bu}$ fonksiyonlara erişimde kullanıcıların rol bazlı yetkilendirmesi sağlanmıștır. Projede yazılım teknolojisi olarak, Php programlama dili, Html 5, Css3, JQuery ve Oracle veri tabanı kullanılmaktadır.
Uygulama iki boyutta değerlendirilebilir. Birincisi, kullanıcı alıșkanlıklarının yönetimi ve enerji politikası noktasında bilinçlendirme çalışmaları, ikincisi ise kurumdaki enerji giderlerinin ve BìT ürünlerinin kayıt altına alınması, yürütülen enerji politikalarının takibi ve bu noktada gider kalemlerindeki değişimin gözlenmesi şeklinde açılanabilir. Uygulamanın gerçekleştirimi için 25 tablo kullanılmıştır. Bu tabloların etkin kullanımı için ilișkisel veri tabanının yeteneklerinden ve özelliklerinden (foreign/primary key, trigger, sequence gibi) faydalanılmıştır.

\subsection{Kullanıcı türleri}

Yeșil BİT'in en önemli unsurlarından biri süreçleri iyileştirip etkinleştirerek enerji tasarrufu sağlamasıdır. Bu noktada organizasyon yapısı içinde doğru rol ve görev dağglımı yapabilmek önemlidir. Uygulamada roller sırasıyla, strateji geliştirme daire başkanlığ birim sorumluları, kurum personelleri ve değişim ajanları şeklindedir. 


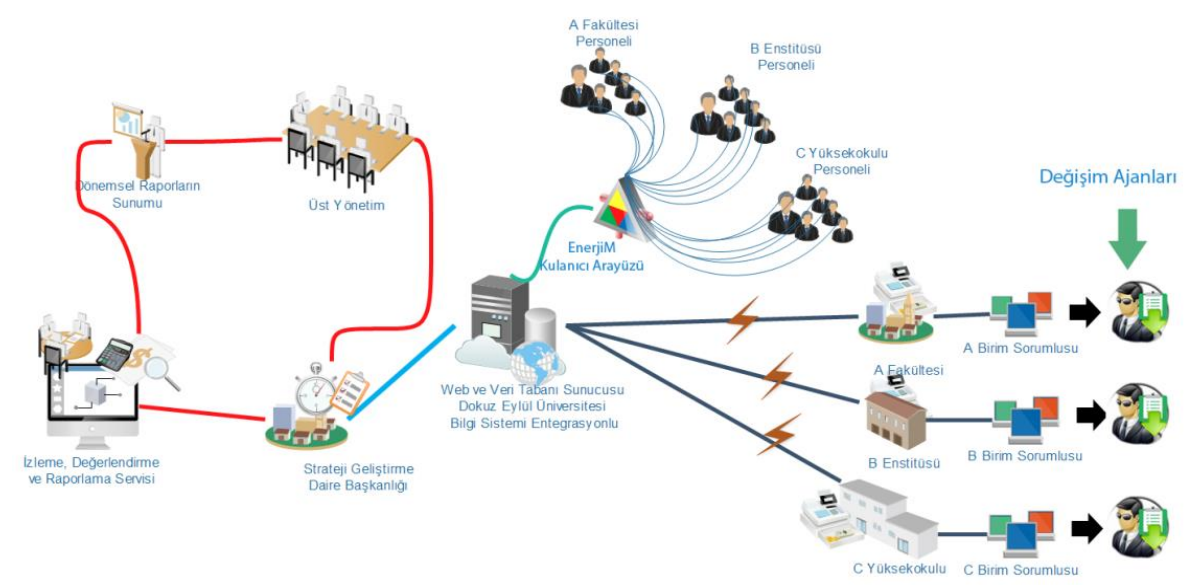

Şekil 6. Projenin roller ve süreçler üzerinde görünümü

Her rolün farklı sorumluluk ve yetki alanları söz konusudur. Kullanıcı türlerinin her biri ayrı önem ve özelliğe sahiptir. Fakat bunlar arasında özellikle enerji politikalarının ve kullanım alışkanlıklarının düzene girmesinde, enerji politikalarının hedefe ulaşmasında, kurum personeli kritik öneme sahiptir. Uygulamanın test sürecinden elde edilen ekran görüntüleri Şekil 7 ve Şekil 8 üzerinde gösterilmektedir. Birim sorumluları tarafından birim enerji gider kalemleri program sayesinde girebilmekte, kullanıcıların üzerlerindeki BİT ürünleri envanterine erişebilmekte, ilgili birimdeki personele duyuru ve haber iletilebilmektedir. $\mathrm{Bu}$ ekranlar sayesinde, birimlerin enerji tüketimlerinin aylık/yıllık olarak görülmesi sağlanmakta ve birime kayıtlı personel listesi ve bu personellerin üzerindeki cihaz envanterine ulaşabilmektedir. Enerji giderleri bütçe kalemlerini bu uygulama aracillğ takip edebilmekte ve strateji geliştirme daire başkanlığı ile uygulama üzerinden haberleşebilmektedir. Uygulamada kullanılan birim ve birim kodları üniversitenin sahip olduğu ve diğer projelerde kullanılanlar ile aynıdır. Bu sayede gereken durumlarda diğer projelerden ilgili birimler ile ilgili farklı verilere (Bilimsel araștırma veya TÜBİTAK proje bilgileri gibi) kolaylıkla ulaşabilecektir. Bu durum, projeler aracllığı ile birim envanterine giren BíT ürünlerini de kontrol altına alabilmeye imkan sağlamaktadır.

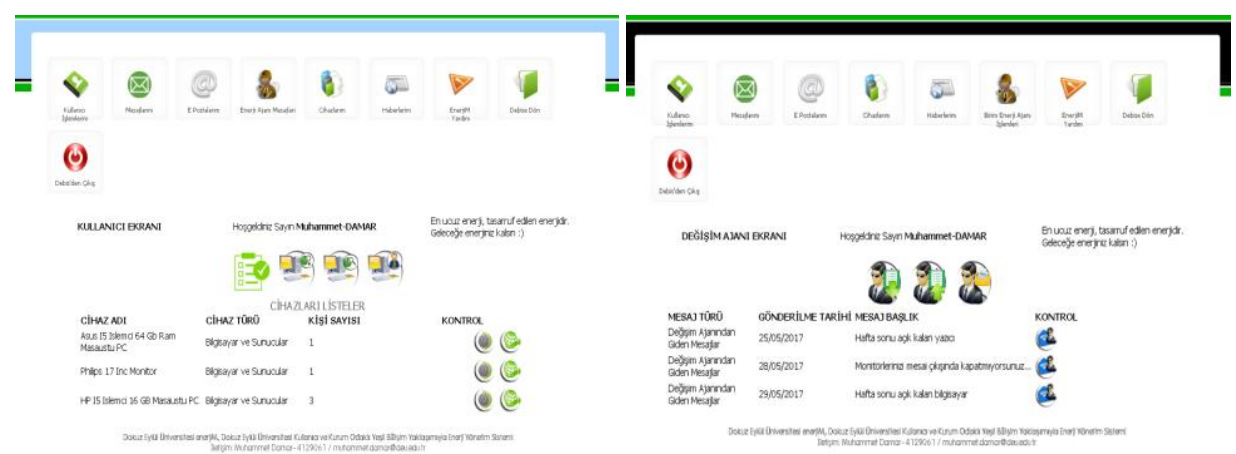

Şekil 7. Kullanıcı ve değișim ajanı ekranlarından görünüm 


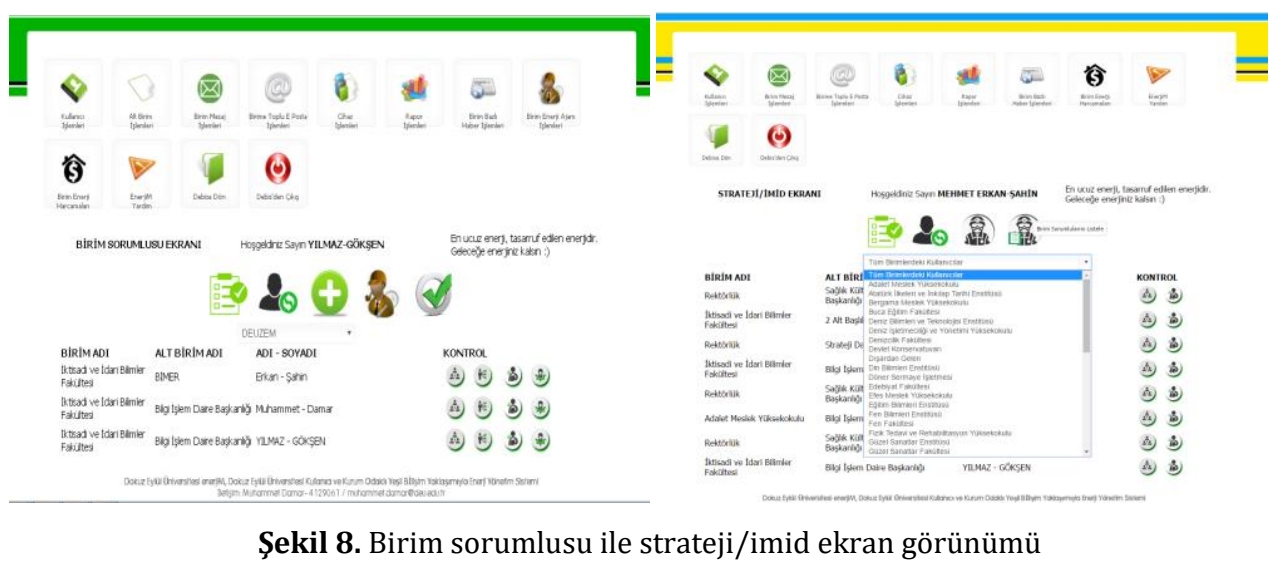

Aynı zamanda her birimin altında sanal birim oluşturmak mümkündür. Birimler içerisinde özelleştirme yapılabilir ve daha özel raporlara ulaşlabilir. Bir diğer rolümüz "Akıllı Enerji Yönetimi: Enerjim" uygulamasında, akıl ve sürekli iyileşme adına kritik öneme sahip değişim ajanlarıdır. Değişim ajanları, kullanıcıların BİT ürünleriyle kullanıcıların hatalı olduğu durumlarda, uyarı mesajları gönderebilmektedir. $\mathrm{Bu}$ uyarı mesajları, bilgisayar veya yazıcı gibi BíT cihazlarının kullanılmadıkları zamanlarda kapatılmaması (işyerinden çıkışta, öğle aralarında) durumlarında gönderilmektedir. Yazıcılardan aşırı çıktı almak, yazıcıları kişisel amaçlı kullanmak uyarı mesajlarının diğer konularıdır. Gönderilen her mesaj kayıt altına alınmakta ve birim yöneticileri tarafından görünebilmektedir. $\mathrm{Bu}$ sayede kullanıcıların BİT kullanım alışkanlıkları üzerinde kontrol ve denetim sağlanmaktadır.

Kurumlar gelenekselleşmiş yönetim sistemlerinden kurtulmak için yeni ve sistematik bir yaklaşım olan değişim mühendisliğini uygulamaktadır $[\mathbf{3 7 , 3 8}]$. Değişim mühendisliğinin en önemli amacl; organizasyonda performans düzeyini yükseltmektir ve başlıca performans göstergeleri maliyet, kalite, hız ve hizmettir [37]. Değişim ajanları aynı zamanda değişim mühendisi gibi hareket ederler. Kurum yöneticilerine kurum içi enerji politikasının gelişmesi için birim içi işletilen süreçler ile ilgili kritik ve önemli bilgiler sunacağı düşünülmektedir. Enerji politikalarının birimde yayılması ve seslendirilmesinde değişim ajanları önemli görevlere sahiptir. Kurum içi eğitimleri ilk alacak kişiler değişim ajanlarıdır. Bilinçlendirmede ve kurum içi verimli enerji tüketiminde ve çevre bilinci oluşturulmasında aktif rol oynamaktadır. Son rol olarak tercih edilen ve organizasyon yapısı üzerinde önemli bir yere sahip olan strateji geliştirme daire başkanlığıdır. Bu birim, kurum içi enerji giderlerinin kayıt altına alınmasını, takibini, hedeflerin belirlenmesini, üst yönetime ve kamuya çeşitli raporlar ile bilgi verilmesinden sorumludur. Özetle, yazılımın kapsamı enerji yönetiminin sağlanabilmesi için, enerji giderlerinin kayıt altına alınıp izlenebilmesi, dönemsel hedefler konulması, üst yönetime ve birimlere raporlamaların yapılabilmesi için verilerin saklanması ve sunulması, kullanıcılar üzerinde etkin bir enerji yönetimi yürütebilmek için bir ortam sağlanması şeklindedir. $\mathrm{Bu}$ bağlamda olușturulan rollerin farklı sorumluluk alanları, yazılım içerisinde yetkilendirildikleri farklı ara yüzler söz konusudur. 


\section{Sonuç ve Öneriler}

Gerçekleştirilen çalışmanın, yazılım gerçekleştirim süreçleri, ihtiyacın ele alındığı sektör, sektör içerisinde çözüm bulduğu problemler ve probleme getirdiği yaklaşım açısından bu alanda gerçekleştirilen öncü çalışmalardan olduğu ifade edilebilir. Çalıșmada çözüm olarak sunulan uygulama, enerji yönetiminin sağlanabilmesi, enerji giderlerinin kayıt altına alınıp izlenebilmesi, dönemsel hedefler konulması, üst yönetime ve birimlere raporlanması, kurum personelinin BİT envanterinin yönetimi ve birim içi haberleşme gibi birçok fonksiyona sahiptir. Yapılacak verimlilik ve tasarruf çalışmaları üniversitenin büyüklüğü, BİT cihaz sayıları ve tüketim miktarları dikkate alındığında önemli ve kurum lehine olduğu düşünülebilir.

Öneri olarak, uygulamanın diğer kamu kurumlarına da örnek teşkil edecek şekilde, kurum genelinde diğer bütçe kalemlerini de içine alan bir bütçe kontrol sistemi dönüştürülebilir. Bu sayede kurumların bütçeleri ile etkinlikleri arasında etkileşim kontrol altına alınıp, yönetimi kolaylaştırılabilir. Proje farklı üniversitelerde uygulanabilir hale getirilebilir. Pilot bir iki üniversite içinde sistemlerin incelenmesi ile kurgunun tüm üniversiteler için çalıştırılabilir hale getirilmesi sağlanabilir. Bunun yanında proje, üniversitelerin Bilimsel Araştırma Projesi (BAP) fonu tarafindan desteklenebilir. Kamu ve özel kuruluşlar, çevre dostu davranmaya özendirilebilir, iș süreçlerinin daha yeșil ve çevreci olmasına gayret gösterilebilir.

Projenin daha akıllı hale getirilebilmesi için, projede istemci-sunucu mimarisiyle desteklenen, kurum çalışanlarının bilgisayarlarına kurulabilecek bir yazılım ile bilgisayar kullanımları kurum genelinde kontrol edilebilir. Bu sayede sistem çok daha akıllı hale gelebilir. Kullanıcıların tüketim alışkanlıklarının ve enerji giderlerinin kayıt altına alınması ile ise de bu bağlamda daha etkin kurum içi politikaların sürdürülmesi sağlanabilir. Farklı üniversiteler ile birlikte çalışma, üniversitelerin kendi yapılarından doğabilecek özel durumların așılması ile projenin daha başarılı olabilmesi için firsatlar sağlayabilir. Farklı üniversitelerin aynı sistemi kullanması, üniversiteler arasında yürütülen politikalar, belirlenen hedefler ve hedeflere ulaşma konusunda bir kıyaslama sağlayabilir.

\section{Kaynakça}

[1] Adamson, M. Hamilton R. Hutchison K. Kazmierowski K. Lau J. Madejski D. Macdonald N. 2005. Environmental Impact Of Computer Information Technology in An Institutional Setting: A Case Study At The University of Guelph. http://www.uoguelph.ca/isc/docu ments/050602environcs_000.pdf (Erişim Tarihi: 27.12.2016).

[2] Bayraç, N.H. 2013. Enerji Kullanımının Küresel Isınmaya Etkisi ve Önleyici Politikalar, Eskişehir Osmangazi Üniversitesi Sosyal Bilimler Dergisi, Cilt 11, Sayı 2, s.229-260.

[3] Bertaldi, P. Atanasiu, B. 2009. Electricity Consumption And Efficiency Trends in European Union - Status Report 2009. http://iet.jrc.ec.europa.eu/sites/def ault/files/documents/ie_energy_pr ess_event/status_report_2009.pdf (Erişim Tarihi: 27.12.2016).

[4] Cook, G. Horn, V.J. 2011. How Dirty İs Your Data? http://www.greenpeace.org/intern ational/Global/international/public ations/climate/2011/Cool\%20IT/d irty-data-report-greenpeace.pdf/ (Erişim Tarihi: 27.12.2016).

[5] Çalıkoğlu, E. 2013. Enerji Yönetimi Politikası. Enerji Yönetimi ve 
Politikaları (s.45-69), (Ed.) Ergün, Y. Tanışlı, M., Anadolu Üniversitesi Açık Öğretim Fakültesi, Eskişehir.

[6] Çavdar, D. Alagöz, F. 2013. Yeşil Veri Merkezlerinde Enerji Verimliliği, (Bildiri No: 276), Akademik Bilişim 2013, Düzenleyen: Akdeniz Üniversitesi 23-25 Ocak 2013 Antalya.

[7] Çevreci Bilişim, 2010. Kamu-Bib XII. Dönem Belge Grubu Raporu, Türkiye Bilişim Derneği. http://kamu-bib.org.tr/kamubib12/rapor/RP3-2010.pdf (Erişim Tarihi: 27.12.2016).

[8] Çiftlik, S. Handırı, İ. Beyhan, M. Akçi, U.A. Ilgar, M. Gönüllü, T.M. 2009. Elektrikli ve Elektronik Atıkların (EAtık) Yönetimi, Ekonomisi ve Metal Geri Kazanım Potansiyeli Bakımından Değerlendirilmesi. TÜRKAY 2009, Türkiye'de Katı Atık Yönetimi Sempozyumu, Yıldız Teknik Üniversitesi, 15-17 Haziran 2009, İstanbul.

[9] Damar, M. Gökșen, Y. Doğan, 0. 2015. Yeşil Bilişim: Bir Kamu Kurumu Örneği ve Politika Önerileri. 2. Yönetim Bilişim Sistemleri Kongresi Bildiri Kitabı (165-179). 8-10 Ekim, Erzurum.

[10] Doküman ve Süreç Yönetimi Nedir, 2013. envision. http://www.envision.com.tr/about_ dms.aspx (Erişim Tarihi: 27.12.2016).

[11] Dodi, K. 2010. Türkiye'de Yenilenebilir Enerji-Limitsiz Enerji. http://www.limitsizenerji.com/test _baran/wpcontent/uploads/2010/02/YEKKad irDodi.pdf (Erişim Tarihi: 27.12.2016).

[12] Elektrik İşleri Etüt İdaresi Genel Müdürlüğü 2011. Yenilenebilir Enerji Genel Müdürlüğü-Enerji Tasarrufu Çalışmaları, http://www.eie.gov.tr/eieweb/turkce/en_tasarrufu/konut_ul as/bina_ulas.html (Erişim Tarihi: 27.12.2016).

[13] Lee, C.H. Chang, C.T. Fan, K.S. Chang, T.C. 2004. An Overview of Recycling and Treatment of Scrap Computers, Journal of Hazardous Materials. Cilt 114 Sayı 1-3, s.93100. DOI: 10.1016/j.jhazmat.2004.07.013

[14] Enerji Verimliliği Derneği, 2010. Türkiye Enerji ve Enerji Verimliliği Çalışmaları Raporu 'Yeşil Ekonomiye Geçiş'. http://www.enver.org.tr/UserFiles /CKUpload/Upload/tevem-2.pdf (Erişim Tarihi: 27.12.2016).

[15] Elektromanyetik Kirlilik, 2015. Cevreonline.

http://cevreonline.com/elektroman yetik-kirlilik/ (Erişim Tarihi: 27.12.2016).

[16] Elhasoğlu, D. 2006. Elektromanyetik Kirliliğin Zararlı Etkileri. Çukurova Üniversitesi Fen Bilimleri Enstitüsü, Fizik Anabilim Dalı Yüksek Lisans Tezi, 135s, Adana.

[17] Türkiye'de ve Dünya'da E-atık, 2016.

http://www.eagd.org.tr/turkiyedeve-dunyada-e-atik/ (Erişim Tarihi: 27.12.2016).

[18] Greener and Smarter, 2010. ICTs, the Environment and Climate Change, Organisation for Economic Co-operation and Development. http://www.oecd.org/site/stitff/45 983022.pdf (Erişim Tarihi: 27.12.2016).

[19] Güngör, M. Saygl, N. Bolat, A. Çaycı, D. Tekin, A.M. 2010. Yeşil Bilişim 2010 Raporu, Bilgi Teknolojileri ve İletişim Kurumu Sektörel Araștırma ve Stratejiler Dairesi Başkanlığ, https://www.btk.gov.tr/File/?path $=$ ROOT $\% 2 \mathrm{~F} 1 \% 2 \mathrm{FDocuments} \% 2 \mathrm{FSa}$ yfalar\%2FArastirma_Raporlari\%2F Yesil_Bilisim.pdf (Erişim Tarihi: 27.12.2016). 
[20] Harper, R., Rodden, T. Rogers, Y. Sellen, A. 2008. Being Human: Human-Computer Interaction in the year 2020. Microsoft Research Ltd. England, $100 \mathrm{~s}$.

[21] Hepbaşlı, A. 2010. Enerji Verimliliği ve Yönetim Sistemi: Yaklașımlar ve Uygulamalar. Esen Ofset, İstanbul, $960 \mathrm{~s}$.

[22] ITU, 2008. ITU and Climate Change, International Telecommunication Union http://www.itu.int/dms_pub/itut/oth/23/01/T23010000030002P DFE.pdf (Erişim Tarihi: 27.12.2016).

[23] Karagöl, B. 2013. Bilgi ve İletişim Teknolojilerinin Enerji Verimliliğine Katkısı. Kalkınma Bakanlığı Bilgi Toplumu Dairesi Başkanlığl, Uzmanlık Tezi. http://www.bilgitoplumu.gov.tr/w p-

content/uploads/2015/01/Bilgi_ve _Iletisim_Teknolojilerinin_Enerji_Ve rimliligine_Katkisi.pdf (Erișim Tarihi: 27.12.2016).

[24] Kaya, S.İ. 2012. Uluslararası Enerji Politikalarına Bir Bakış: Türkiye Örneği. Türkiye Barolar Birliği Dergisi, Sayı 102, s. 269-288.

[25] Merdan, T. 2010. Sanallaştırmanın Bilgi Teknolojilerine Getirdiği Yenilikler ve Uygulamaları. Haliç Üniversitesi, Fen Bilimleri Enstitüsü, Yönetim Bilişim Sistemleri Programı, Yüksek Lisans Tezi, s.81, İstanbul.

[26] Mines, C. 2011. Inside Green IT "4 Reasons Why Cloud Computing is Also A Green Solution". GreenBiz Group Inc. http://www.greenbiz.com/blog/20 11/07/27/4-reasons-why-cloudcomputing-also-green-solution (Erişim Tarihi: 27.12.2016).

[27] Özbakır, P. 2006. Enerji Yönetimi. Yıldız Teknik Üniversitesi Fen Bilimleri Enstitüsü Doktora Tezi, s.146, İstanbul.
[28] Resmi Gazete, 2008. Elektrikli ve Elektronik Eşyalarda Bazı Zararlı Maddelerin Kullanımının Sinırlandırılmasına Dair Yönetmelik. http://www.resmigazete.gov.tr/esk iler/2008/05/20080530-3.htm (Erișim Tarihi: 27.12.2016).

[29] Tebbutt, D. Atherton, M. Lock, T. 2009. Green IT For Dummies, http://www.hp.com/hpinfo/globalc itizenship/environment/productde sign/GreenITforDummiesSpecialEdi tion.pdf (Erişim Tarihi: 27.12.2016).

[30] Turkcell Sürdürülebilirlik 2011 Raporu, 2011. Turkcell İletişim Hizmetleri A.S http://d.turkcell.com.tr/Downloads /hakkimizda/pdf/kurumsal-sosyalsorumluluk-raporu-2011_v2.pdf (Erişim Tarihi: 27.12.2016).

[31] Türk Telekom'dan Çevre Dostu Teknolojilerle Daha Yaşanabilir Bir Dünya, 2014. Türk Telekomünikasyon A.S http://uzmanpara.milliyet.com.tr/k ap-haberi/turk-telekomdan-cevredostu-teknolojilerle-dahayasanabilir-bir-dunya---basinaciklamasi/270401/ (Erişim Tarihi: 27.12.2016).

[32] Ünal, R.S. Onur, A. Dursun, B. Serhan, D. 2013. Sürdürülebilir Kalkınma İçin Bilişim, Bölgesel Çevre Merkezi Türkiye. http://www.vodafone.com.tr/Vodaf oneHakkinda/Surdurulebilir_Kalkin ma_icin_Bilisim_Raporu.pdf (Erişim Tarihi: 27.12.2016).

[33] 2011-2015 Stratejik Planı, 2010. Dokuz Eylül Üniversitesi 2011-2015 Stratejik Planı. Dokuz Eylül Üniversitesi Strateji Geliştirme Daire Başkanlığı İzmir, 93s.

[34] 2015 Performans Raporu, 2014. 2015 Mali Yılı Nihai Performans Programı, Dokuz Eylül Üniversitesi Strateji geliștirme daire Başkanlığ 
M. Damar vd. / Yeșil Bilişim Yaklașımıyla Kullanıcı ve Kurum Odaklı Enerji Yönetim Sistemi

Bütçe ve Performans Programı Şube Müdürlüğü. İzmir, 106s.

[35] 10 Key Elements of a Green IT Strategy, (2007). Gartner. https://www.gartner.com/doc/559 114/-key-elements-green-it (Erişim Tarihi: 27.12.2016).

[36] Cevre Kanunu, 1983. Kabul Tarihi: $\quad$ 9.08.1983 Sayı.18132. http://www.mevzuat.gov.tr/Mevzu atMetin/1.5.2872.pdf (Erişim Tarihi: 27.12.2016).
[37] Demir Y. 2008. İşletme Yönetimi Açısından Değişim Mühendisliği Yaklaşımı ve Uygulanabilirliği, e-Journal of New World Sciences Academy Social Sciences, Cilt. 3, Sayı. 2, s. 286-295.

[38] Aktan C.C. 2011. Organizasyonlarda Değişim Yönetimi: Değişim Mühendisliği. Organizasyon ve Yönetim Bilimleri Dergisi, Cilt 3, Sayı 1, s. 67-96. 